\title{
Diablotextor
}

\section{La prosa de imaginación española de los siglos XVI y XVII: el nacimiento de la novela moderna}

\author{
JUAN RAMÓN MUÑOZ SÁNCHEZ \\ UNIVERSIDAD DE JAÉN
}

La prosa de imaginación experimentó un desarrollo inusitado en la literatura hispánica de los siglos XVI y XVII, sin parangón con los sistemas literarios de otros reinos y lugares europeos, lo mismo en la rica diversidad de propuestas y modos narrativos que en la cantidad, no exenta de calidad, de representantes de cada serie genérica. El resultado más conspicuo no fue otro que la génesis de la novela moderna, por la quiebra mayúscula que supuso en la ficción el diseño de un mundo posible de aire 'realista' o empirista cuya referencialidad era la vida ordinaria o la experiencia cotidiana, la ambientación contemporánea, el espíritu crítico de la sociedad y las costumbres circundantes, la mezcla de estilos con predominio del sermo humilis y la oralidad, la conformación de personajes en construcción, dotados de vida interior, aprendizaje y evolución psicológica, y la dignificación literaria de personajes humildes en algunos textos, así como por el empleo de técnicas y estrategias discursivas de distinta índole que van desde la ambigüedad, la ironía, la parodia y la polisemia hasta el perspectivismo, la heteroglosia, la hibridación y la autorreferencialidad.

Aunque la ficción en prosa conoció un progreso más o menos continuado, más o menos ininterrumpido, en el devenir del tiempo en cuestión, tanto en su cultivo por parte de los autores como en su edición promovida por impresores, libreros y traductores, se pueden establecer cuatro periodos 
cruciales o momentos estelares de singular ductilidad de las formas narrativas, de readaptación y renovación de los viejos modos y cauces de expresión, de experimentación e innovación y de emergencias modulares discursivas flamantes.

\section{Primer periodo (1489-1513)}

El primero de ellos, que coincide con el inicio de la impresión de textos de ficción en los reinos peninsulares, iría, aproximadamente, desde 1489 hasta 1513. Está señalado por la segunda fase o la etapa central de la ficción sentimental, por el florecimiento de la ficción caballeresca, por la La Celestina, por la difusión de algunas colecciones de cuentos y por la publicación de significativas traducciones al castellano.

La ficción sentimental, que había tenido su etapa inicial entre 1440 y 1460 a partir de la composición del Siervo libre de amor (h. 1440), de Juan Rodríguez del Padrón, alcanzó su apogeo entre 1474 y 1500, ya durante el reinado de Isabel I de Castilla, con la redacción hacia 1475 o 1476 de Grimalte y Gradisa y Grisel y Mirabella, de Juan de Flores, y, en la década de los ochenta, de Arnalte y Lucenda y Cárcel de amor, de Diego de San Pedro, y con su posterior transformación de manuscritos en impresos en el primer lustro de los años noventa: en 1491, en Burgos, por Fadrique Biel de Basilea, se publica Arnalte y Lucenda, en 1492, en Sevilla, por Cuatro Impresores Alemanes, Cárcel de amor, de San Pedro, y en 1495, en Lérida, por Enrique Botel, Grimalte y Gradisa y Grisel y Mirabella, de Flores. De las cuatro obras, la Cárcel de amor no solo se reeditó, antes del cambio de siglo, tres veces más, una en 1493, en Zaragoza, por Pablo Hurus, otra en 1496, en Burgos, por Fadrique Biel de Basilea, y otra en 1500, en Toledo, por Pedro Hagenbach, sino que se tradujo al catalán en 1593 y fue continuada por Nicolás Núñez en 1496, con el título Tratado que hizo Nicolás Núñez sobre el que San Pedro compuso de Leriano y Laureola llamado Cárcel de amor, publicado a prosecución del texto de San Pedro en la edición burgalesa de 1496. Es así como se institucionalizó la serie genérica de la ficción sentimental, que, con diez representantes más, se alargó durante la primera mitad del siglo XVI, hasta 1548 en que se publica el Proceso de cartas de amores, de Juan de 
Segura; al mismo tiempo que se conformó un género editorial, que de algún modo se mantuvo vigente durante todo el siglo $\mathrm{XVI}$, merced sobre todo al extraordinario éxito de la Cárcel de amor, que se reeditó en veinticuatro ocasiones entre 1501 y 1598, y, en menor medida, de Grisel y Mirabella, que alcanzó ocho ediciones más entre 1514 y 1562. A ello hay que sumar que fue un éxito de carácter internacional, habida cuenta de que, desde 1493 hasta 1660 , algunos de los referentes paradigmáticos del género se tradujeron, en veinticinco ocasiones, a más de siete lenguas. La ficción sentimental, aunque de raigambre medieval y cortesana y con nítidos antecedentes clásicos e italianos en las Heroidas, de Ovidio, y en la Elegia di madonna Fiammetta, de Giovanni Boccaccio, aportó, en sus cien años largos de historia, en su sorprendente variedad y en su constante evolución y actualización, la introspección del sentimiento amoroso, la expresión de distintos estados anímicos, el tono confesional, el desenlace luctuoso, el elemento autobiográfico, la alegoría, el molde epistolar general y el uso interno del intercambio de misivas ${ }^{1}$.

Los libros de caballerías castellanos, aunque hunden sus raíces en la Edad Media, nacen como serie genérica y género editorial en el último decenio del siglo XV, con la supuesta edición perdida del Amadís de Gaula, de Garci Rodríguez de Montalvo, en 1495 o 1496 en Sevilla, Burgos o Medina del Campo, que era una refundición de los tres libros del Amadís medieval -redactado quizá en el siglo XIV en deuda con la materia de Bretaña y modificado en el $\mathrm{XV}_{-}$, completada con un cuarto de su propia cosecha; se extiende, con un corpus que fluctúa entre los sesenta y setenta integrantes, a lo largo de todo el siglo $\mathrm{XVI}$, y aun tiene presencia literaria y editorial en el primer cuarto del siglo XVII, con la publicación original, en 1602 en Valladolid, del Policisne de Boecia, de Juan de Silva, con la estampación conjunta, en 1623 en Zaragoza, de las cuatro partes del Espejo de príncipes y caballeros, con la confección anónima e inédita de la Quinta parte del Espejo de príncipes y caballeros, con la Quinta y Sexta parte que compuso el jurista Juan Cano López entre 1637 y 1640 (Ramos, 2016) y con la reedición de unos veinte libros

\footnotetext{
${ }^{1}$ Sobre la ficción sentimental, véase Whinnom (1983), Deyermond (1993 y 1995), Gwara y Gerli (1997), Rohland de Langbehn (1999), Cortijo Ocaña (2001) y Núñez Rivera (2015: 21$100)$.
} 
de caballerías escritos en la centuria anterior. El primer ápice de publicaciones de libros de caballerías, aunque es un reguero incesante hasta la mitad del siglo, se produce entre 1508 y 1512, en que ven la luz la primera edición conservada del Amadís de Gaula (Zaragoza, 1508), de Montalvo, su primera continuación, Las sergas de Esplandián (Sevilla, 1510), de Montalvo, su segunda continuación, el Florisando (Salamanca, 1510), del clérigo Rodrigo Páez de Ribera, el Palmerín de Oliva (Salamanca, 1511), el Primaleón (Salamanca, 1512), de Francisco Vázquez, y el Caballero Zifar (Sevilla, 1512). En este impulso editorial se erige el primer paradigma de la serie, el "inicial", representado por la readaptación a los nuevos tiempos del Amadís de Gaula, de Montalvo, cuyo ciclo habría de sumar doce libros, en torno al sujeto, la forma y la finalidad. El sujeto es "la narración de las aventuras bélicas y amorosas de caballeros y damas que ofrecen una imagen ideal del mundo de la caballería"; la forma, "una estructura narrativa elaborada, en donde juega una gran importancia la utilización de estructuras folclóricas"; la finalidad, "crear una historia fingida, una obra en donde sea posible el didactismo, la defensa de una determinada ideología" (Lucía Megías y Sales Dasí, 2008: 70). A este primer paradigma no solo se agrega el ciclo de los Palmerines, que tendrá continuación años después, en 1533, con la publicación, en Valladolid, del Platir, sino también un intento de contrarrestar el mundo idealizado del Amadís con una variante más 'realista' o 'verosímil', encabezada por el Florisando, de Pérez de Ribera, y proseguida, entre otros títulos, por el Floriseo (Valencia, 1516), de Fernando Bernal, el Lepolemo (Valencia, 1521), de Alonso de Salazar, y el Lisuarte de Grecia (Sevilla, 1526), de Juan Díaz.

Sucede que los libros de caballerías, desde el principio y en su proceso de desarrollo hasta por lo menos la mitad del siglo XVI, están, como género narrativo y como género editorial, "en estrecha relación con los sueños y con la mentalidad práctica de la sociedad que los promovía y los consumía" (Cátedra, 2007: 41), al extremo de "representar la ideología del Estado moderno" y, llegado el caso, de participar "en la propaganda de la política imperial [...] a través de una serie de imágenes de representación del poder real de tipo providencialista y teocéntrico, profético y mesiánico" (Marín Pina, 1996: 105); y, si puede que al principio, en el nacimiento editorial del género y el 
establecimiento del corpus, la alta aristocracia y la nobleza, que estaban viendo cómo la sociedad y los códigos caballerescos se estaban transformando en cortesanos, cómo la caballería real estaba siendo reemplazada en su labor guerrera por los ejércitos profesionales, desempeñaran un papel clave, con el paso del tiempo devino el modo narrativo más popular y uno de los más seguidos por el público femenino. La serie genérica de los libros de caballerías castellanos constituye, en efecto, tanto por la cifra de su corpus textual como por la cantidad de reediciones que se hicieron de ellos, tanto por las traducciones como por las continuaciones en otras lenguas, en especial del Amadís de Gaula, el mayor éxito editorial del siglo XVI dentro y fuera de las fronteras de la Monarquía Hispánica; un triunfo harto reconocible por la complexión de los volúmenes, imponentes infolios de alrededor de trescientos folios, por las portadas con un grabado de un caballero jinete y por la puesta en página a doble columna, letra gótica, inicial adornada e ilustrada con grabados².

En la parte final del siglo XV y a lo largo de la primera mitad del siglo XVI, aproximadamente entre 1490 y 1530, se desarrolló un género de escritura, que se convirtió raudamente en un género editorial de notable éxito comercial, directamente emparentado con los libros de caballerías: la narrativa caballeresca breve. Se trata de un rico y variado corpus compuesto por una veintena de textos, en su mayoría de origen medieval, pero adaptados a la sensibilidad de la época, trasladados del francés, del catalán y, ocasionalmente, del italiano o escritos en origen en castellano. Tuvieron una divulgación editorial uniforme y homologada, en formato en cuarto no superior a ocho pliegos, con grabados y letra gótica, impresos en Toledo, en Burgos y, sobre todo, en Sevilla, en la oficina tipografía de Jacobo Cromberger. Algunos de los primeros títulos son: Historia de Enrique Fi de Oliva (Sevilla, 1498), Crónica popular del Cid (Sevilla, 1498), Historia de Oliveros de Castilla y Artús de Algarve (Burgos, 1499), Libro del esforzado caballero conde Partinuplés (Sevilla, 1499), Historia de la Doncella Theodor (Toledo, entre 1500-1503), Historia de la reina Sebilla (Toledo, 1500-1503), Historia del rey Canamor y del

\footnotetext{
2 Sobre los libros de caballerías, aparte de las referencia citadas, veáse Eisenberg (1982), Eisenberg y Marín Pina (2000), Lucía Megías (2000), Guijarro Ceballos (2007a: 37-138, y 2007b), Haro Cortés y Lucía Megías (2019 y 2020), y, aunque circunscrito a la primera etapa, Bognolo (1997).
} 
infante Turián su hijo (Burgos, 1509), Crónica del conde Fernán González (Sevilla, 1509) y Roberto el Diablo (Burgos, 1509) ${ }^{3}$.

La Celestina, preclaro representante de la comedia humanística cuyo pedigrí literario se remonta a la comedia latina y a la comedia elegíaca del siglo $\mathrm{XII}$, es la obra más revolucionaria de este primer momento y, conforme a su originalidad artística -la erección de un mundo 'realista' verosímil en contienda, que refleja la honda crisis de finales del siglo XV en todos los órdenes de la vida; la ambigüedad que rezuma por los cuatro costados; su condición de parodia de la ficción sentimental; la compleja individualidad de sus personajes y su rica variedad; la polifonía de voces; la variedad de registros; la extraordinaria importancia que desempeñan los estratos bajos y marginales de la sociedad, etc.-, el primer hito, pese a su condición genérica de ficción dialogada, que conducirá a la invención de la novela moderna a caballo entre los siglos XVI y XVII. Como es bien sabido, La Celestina tuvo una génesis muy compleja desarrollada en tres fases fundamentales, si dejamos de lado, entre otros añadidos ajenos, los del corrector Alonso de Proaza: 1) la redacción del primer auto y de las primeras líneas del segundo, realizadas por el "antiguo autor" probablemente entre 1492, data de la edición príncipe de la Cárcel de amor, y 1496, en que se imprime por primera vez la Opera omnia de Francesco Petrarca; 2) la continuación del texto por Fernando de Rojas, hasta culminar la Comedia de Calisto y Melibea, dividida en dieciséis autos y acompañada por los paratextos preliminares y finales, que hubo de producirse entre 1496 y 1499 , fecha de la edición impresa de Burgos, que es la más antigua conservada; 3) la transformación, efectuada con casi toda seguridad por Rojas, de la Comedia en la Tragicomedia de Calisto y Melibea, dividida en veintiún autos, acompañada de nuevos paratextos preliminares y finales, y ampliamente revisada, que hubo de producirse entre 1500, luego de la primera recepción de la Comedia, y 1502, en que se supone que pudo haber una edición, no conservada, del texto en Sevilla, por cuanto la primera que ha llegado hasta nosotros lo constituye la de Zaragoza de 1507, publicada un año después de la traducción italiana que vio la luz en Roma. La Celestina, además, es un texto pionero o inaugural en razón de que, más allá de su rotundo éxito editorial, pues se imprimió más de cien

\footnotetext{
${ }^{3}$ Sobre la narrativa caballeresca breve, véase Infantes (1991 y 1996) y Baranda (1995).
} 
veces entre 1499, año de la edición burgalesa de la Comedia, y 1632, en que fue incluida en el índice inquisitorial de Antonio Zapata, conformó una progenie de continuaciones y emulaciones circunscritas al interregno comprendido entre 1534 y 1554: la Segunda comedia de Celestina (Medina del Campo, 1534), del prolífico Feliciano de Silva, la Tercera parte de la tragicomedia de Celestina (Medina del Campo, 1536), de Gaspar de Gómez, la Tragicomedia de Lisandro y Roselia llamada Elicia y por otro nombre cuarta obra y tercera Celestina (Salamanca, 1542), de Sancho Muñón, la Tragedia Policiana (Toledo, 1547), de Sebastián Fernández, y la Comedia Selvagia (Toledo, 1554), de Alonso de Villegas (Baranda, 1992). Y eso sin contar con la impronta decisiva que dejó en textos tan significativos y dispares como La Lozana andaluza (Venecia, 1528), de Francisco Delicado, La Dorotea (Madrid, 1632), de Lope de Vega, y aun en El casamiento engañoso y El coloquio de los perros, de Cervantes.

En el capítulo de las traducciones, cabe mencionar la publicación de dos obras directamente emparentadas con la ficción sentimental, la Historia muy verdadera de dos amantes, Euríalo franco y Lucrecia senesa (Salamanca, 1496), de Eneas Silvio Piccolomini, y La Fiameta (Salamanca, 1497), de Giovanni Boccaccio; las cuales se acometieron posiblemente al socaire del éxito de las publicaciones de los textos de Juan de Flores y Diego de San Pedro, no sin que la segunda, en su versión italiana, constituyera un referente intertextual de primer orden de Grimalte y Gradisa. Así también, algunas importantes obras de la ficción caballeresca que coadyuvaron al desarrollo de los libros de caballerías castellanos, como, por ejemplo, la Historia de la linda Melosina (Toulouse, 1489), de Jean d'Arras, vertida al castellano por Juan Parix, el Baladro del sabio Merlín (Burgos, 1498); el Tristán de Leonís (Valladolid, 1501), y Tirante el Blanco (Valladolid, 1511), de Joanot Martorell y Joan Martí.

En 1494 se publicó en Sevilla la versión castellana del Decamerón, de Giovanni Boccaccio, con el título de Las cien novelas de Juan Bocacio, basado probablemente en una copia de la versión castellana llevada a cabo en el primer tercio del siglo $\mathrm{XV}$, de la que también dependería el demediado códice escurialense J-II-21. El incunable presenta la peculiaridad de que reemplaza la novela de Griselda por la readaptación humanista de Petrarca, readapta, 
desvirtúa o elimina la cornice y la distribución en jornadas, desordena las novelas, que se numeran correlativamente, e introduce una -la número setenta y tres- ajena al original en lugar de la IX, 5, que falta. Cosechó una cierta celebridad durante la primera mitad del siglo XVI antes de su inserción en el índice de Valdés de 1559, por cuanto se reeditó en cuatro ocasiones: en Toledo, en 1524; en Valladolid, en 1539; en Medina del Campo, en 1543, y en Valladolid, en $1550^{4}$. Es difícil calibrar ponderadamente la influencia directa que pudo ejercer en la literatura española clásica, por cuanto compitió con el original en italiano, que seguramente se leyó más y alcanzó mayor difusión; aun así, hubo de ser significativa tanto en el desarrollo de la novela corta como en otros géneros. No fueron Las cien novelas la única colección de relatos breves que se tradujeron en el periodo, antes bien, en 1489, en Zaragoza, había visto la luz un volumen de contenido misceláneo intitulado Ysopete historiado, que contenía quince cuentos de la Disciplina clericalis (s. XII), de Pedro Alfonso, despojados de su marco junto con las fábulas y facecias de Esopo, Fedro, Remigio d'Arezzo, Aviano, Rómulo, Poggio Barcciolini y la Historia Sigmundae de Leonardo Bruni. En 1493 se publicó, igualmente en Zaragoza, el Exemplario sobre los engaños y peligros del mundo, que es una versión de la famosa colección de cuentos enmarcados didácticos de origen oriental, el Calila y Dimna, trasladados de la versión latina de Juan de Capua. El libro representó un éxito sin paliativos, puesto que se editó dos veces más antes de 1500 (en 1494, por Pablo Hurus, en Zaragoza, y en 1498, por Fadrique de Basilea, en Burgos), doce a lo largo del siglo XVI y constituyó la base de las versiones italianas de Firenzuola (1548) y Doni (1552). En 1510, en Sevilla, se editó -materialmente como un volumen de narrativa caballeresca breve- el Libro de los siete sabios de Roma, que es una versión impresa de la rama occidental de la colección de cuentos orientales enmarcados sobre la leyenda del hijo único de Alcos, rey de Judea, acusado falazmente por una de las mujeres de su harén, el Sendebar o Libro de los engaños, que fue vertido al castellano en 1253 por orden de don Fadrique, hermano de Alfonso X. La colección de los Siete Sabios cosechó un importante éxito, reeditándose en

\footnotetext{
${ }^{4}$ Sobre todo lo relativo al incunable castellano del Decamerón, remitimos a González Ramírez (2021) y a la bibliografía allí citada.
} 
siete ocasiones a lo largo del siglo XVI, la última en 1595, y, después, en pliegos de cordel hasta el siglo XIX.

Quizá la traducción más relevante de este primer momento de desarrollo de la narrativa áurea castellana no fuera otra que la versión, en pulcro y elegante castellano, del Asno de oro, de Apuleyo, obra del arcediano hispalense Diego López de Cortegana, que vio la luz, en Sevilla, en 1513, en el taller de Jacobo Cromberger, sobre la base de la edición comentada, acompañada de diversos paratextos, del Asinus aureus (o Metamorphoses) que el humanista boloñés Filippo Beroaldo il vecchio había dado a la estampa en 1499 o 1500. La versión de Cortegana contó con hasta seis impresiones más en la primera mitad del siglo XVI, antes de su inclusión en el índice de Valdés en 1559: la de Valera de Salamanca, publicada en Sevilla, en un año sin determinar entre 1520 y 1535; la de Tomaris, quizás Pedro Tovans, en Zamora, en 1536; la de Pedro Tovans también en Zamora, en 1539; la de Pedro de Castro en Medina del Campo, en 1543; la de Doménico de Robertis en Sevilla, en 1546; y la de Juan Steelsio en Amberes, en 1551. Después, se editó expurgada en 1584, en Alcalá de Henares, en el taller de Hernán Ramírez, despojada de las escenas eróticas más escabrosas de los libros VIII, IX y X, y en 1601, en Madrid, en el taller de Andrés Sánchez, y en Valladolid, en el de los herederos de Bernardino de Santo Domingo, ambas de nuevo censuradas por distintas manos y muy alejadas ya de la versión original de Cortegana. El impacto que tuvo en las letras hispanas, aunque hubo de esperar hasta la mitad del siglo para fructificar en toda su magnitud, fue formidable, bien que en coalescencia con las transliteraciones de los relatos y diálogos de Luciano de Samósata, habida cuenta de que su lectura e intelección fue fundamental, entre otros, para un elenco de textos entroncados entre sí en su talante humanista, su imitación clásica, la visión crítica de la sociedad y las costumbres contemporáneas y la sátira política, cuales son los relatos de Falqueto y Cíngar insertados en el Baldo (Sevilla, 1542), el Lazarillo de Tormes (Amberes, 1553, la edición más antigua de que se tiene noticia cierta), la Segunda parte de Lazarillo de Tormes (Amberes, 1555), El Crotalón (h. 1556), El viaje de Turquía (h. 1556) y Los coloquios de Palatino y Pinciano (1550-61), de Juan Arce de 
Otálora. Después, fue sencillamente decisivo para Mateo Alemán, Miguel de Cervantes, Francisco de Quevedo y Baltasar Gracián.

\section{Segundo periodo (1550-1560)}

El segundo momento culminante en el desarrollo de la prosa de imaginación española lo constituye la década de 1550 a 1560, en que, impulsados por la Corte internacional y cosmopolita de Carlos $V$, en la que campeaba un ambiente de libertad y tolerancia que propició un fluido intercambio de ideas entre humanistas, letrados y hombres de cultura, por la educación de corte erasmista que el príncipe Felipe comenzó a recibir a partir de 1541, por el humanismo quinientista, por una serie de traducciones del legado clásico y de la literatura italiana, por el proceso y avance natural de la literatura y por mor de la experimentación literaria y la persecución de novedades poéticas en su sentido más amplio, se remozaron algunos de los géneros ya existentes, otros dieron paso a nuevos cauces discursivos y se pergeñaron textos fundacionales de espléndida envergadura estética que, antes o después, propiciaron un formidable cambio de paradigma.

Los libros de caballerías, que acaban de alcanzar el cenit de su apogeo editorial entre los años de 1542 y 1548, no solo padecieron un acusado descenso en el periodo que coincidió con la abdicación de Carlos $\mathrm{V}$ y los primeros años del reinado de Felipe II, aun cuando se estamparon tres títulos nuevos -la Cuarta parte de Don Florisel de Niquea (Medina del Campo, 1551), de Feliciano de Silva, la Primera parte del Espejo de príncipes y caballeros (Zaragoza, 1555), de Diego Ortúñez de Calahorra, y Felixmarte de Hircania (Valladolid, 1556), de Melchor Ortega-, sino que experimentaron una notable trasmutación, que comportó, si no un cambio radical de tendencia, pues el inicial fijado por el Amadís seguirá vigente, sí el establecimiento de un nuevo modelo o prototipo: el de los libros de caballerías de entretenimiento (Lucía Megías y Sales Dasí, 2008: 77-80). Cierto es que a partir de los años veinte y, en especial, de los textos escritos por Feliciano de Silva, pertenecientes al ciclo de los Amadises ${ }^{5}$, se venía produciendo una rectificación en la serie

\footnotetext{
${ }^{5}$ Feliciano de Silva (entre 1480 y 1492-1554), que es el novelista español más importante y más célebre de la primera mitad del siglo XVI, escribió, aparte de la Segunda Celestina (1534), cinco libros de caballerías, pertenecientes todos, en efecto, al ciclo de los Amadises: Lisuarte 
caballeresca del prodesse al delectare, del compromiso y el heroísmo ejemplar a la evasión y el contenido más puramente fantástico y maravilloso. Pero la nueva modalidad o el nuevo paradigma no se instituyó hasta el texto de Ortúñez de Calahorra, del que se llegarían a componer hasta seis continuaciones en años sucesivos ${ }^{6}$, y al que se sumaría el ciclo de Belianís de Grecia ${ }^{7}$. Y es que, en la segunda mitad del siglo XVI, los libros de caballerías, pese al empuje de las nuevas fórmulas narrativas, singularmente de la novela pastoril, mantuvieron su vigencia y vigor editorial, y aun un importante repunte, espoleados quizá por las leyes de reforma de la caballería ciudadana promulgadas por Felipe II en 1562 y 1563 y reactivadas en 1572, entre 1575 y 1590 (Cátedra, 2007: 81-126). Aunque pueda parecer que la banaliza, la defensa explícita e implícita de la prosa de imaginación como un lúdico entretenimiento que recrea los ojos del entendimiento por medio de la invención y el artificio que se opera en estos libros de caballerías constituye un signo de los nuevos tiempos, que, en última instancia, reivindica la autonomía de la literatura como discurso y que, ya manifiesta en el prólogo del Baldo y asimismo en el de Martín Nucio al Cancionero de romances (h. 1548), arribará hasta el conjunto de la obra Cervantes, quien la formulará irónica y soberbiamente en el prólogo de las Novelas ejemplares.

La ficción sentimental, que había puesto fin a su itinerario con la publicación en 1548 del Proceso de cartas de amores que entre dos amantes pasaron y una Queja y aviso contra Amor, del toledano Juan de Segura, y que

de Grecia (1514), que se reeditó nueve veces a lo largo del siglo XVI, seis de ellas en la primera mitad; Amadís de Grecia (1530), que tuvo seis reediciones; las partes I y II de Don Florisel de Niquea (1532), que fue reeditado en cinco ocasiones; Rogel de Grecia o Tercera parte de Don Florisel de Niquea (1535), que tuvo tres reediciones más, y la Cuarta parte de Don Florisel de Niquea (1551), que se volvió a estampar en 1568 en Zaragoza.

${ }^{6}$ A la Primera parte del Espejo de príncipes y caballeros o El caballero del Febo (1555), de Ortúñez de Calahorra, que tuvo seis reediciones más durante el Siglo de Oro, le siguió la Segunda parte (1580), de Pedro de la Sierra Infanzón, que fue vuelta a estampar en cinco ocasiones; la Tercera y Cuarta parte (1588), de Marcos Martínez, que tuvo dos reediciones más; la Quinta parte, anónima, que se conserva en un manuscrito de la Biblioteca Nacional de España en Madrid (ms. 13137), que data del siglo XVII, y las Quinta y Sexta parte que escribió entre 1637 y 1640 Juan Cano López.

${ }^{7}$ Las partes I y II de Don Belianís de Grecia (1545), de Jerónimo Fernández, que tuvo cinco reediciones más a lo largo del siglo XVI, fueron continuadas con la Tercera y cuarta parte del invencible príncipe don Belianís de Grecia (1579), por el mismo Jerónimo Fernández, y con la Quinta parte, obra de Pedro Guiral del Verrio, que no pasó del manuscrito al impreso. Recuérdese que fue justamente el libro de Don Belianís de Grecia el que quiso prolongar Alonso Quijano antes de convertirse en don Quijote. 
justamente con ella, al sintonizar con la eclosión de la moda epistolar de la época (Rico, 2011: 145-154), había demostrado su maleabilidad morfológica, solo tuvo presencia editorial en la década de 1550-1560, con reediciones de la Cárcel de amor, de la Cuestión de amor (1513) y del propio Proceso de cartas de amores. Si bien, dejó manifiesta su impronta en obras y géneros de nuevo cuño como en la Historia de los amores de Clareo y Florisea y los trabajos de la sin ventura Isea, natural de la ciudad de Éfeso, de Alonso Núñez de Reinoso, por la nota femenina que comporta el empleo de una narradora-protagonista, Isea, que se remonta en última instancia a las precursoras de la serie genérica, las Heroidas, de Ovidio, y la Elegia di madonna Fiammetta, de Boccaccio, y en los libros de pastores, por cuanto son dos tipos de ficción que tratan muy por extenso el tema del amor y sus circunstancias y lo abordan desde la introspección psicológica, aun cuando, como señalaba Avalle-Arce (1975: 47), "la novela pastoril [...] marca un nuevo desplazamiento, pero respecto a la novela sentimental. En esta última el amor está presentado dentro de la estructura de la sociedad, si bien en conflicto con ella, mientras que en aquella lo está en estado de naturaleza, previo a la formulación social".

Una de las características primordiales del periodo que nos ocupa lo constituye la interacción e hibridación genérica, la experimentación con diversas regiones de la imaginación en un mismo texto cuyo resultado es, a veces, la creación de un mundo posible nuevo. El caso más significativo no es otro que el Clareo y Florisea, de Reinoso, publicado en Venecia en 1552, que, sólitamente, se considera la primera manifestación genérica de la novela española de tipo griego (Teijeiro Fuentes, 1988 y 2007; González Rovira, 1996: 165-182), cuando en realidad es una suerte de imbricación o mescolanza de géneros: los primeros diecinueve capítulos representan una traducción libre y muy remozada de los Amorosi ragionamenti (1546) de Ludovico Dolce, que a su vez es una traducción incompleta de la versión latina de la novela de Aquiles de Tacio Leucipa y Clitofonte realizada por A. Della Croce en 1544, aunque no se puede descartar que Reinoso conociera la traducción italiana completa de la novela griega de Aníbal de Coccio publicada en 1551 (Marguet, 1999); los capítulos XXII-XXXI incluyen el relato de caballerías -modélico y ejemplar- de don Felesindos; y el último, que transcurre en la Ínsula Pastoril, 
ofrece una nota entre bucólica y sentimental al conjunto desde el que se produce toda la enunciación del relato.

Es importante señalar que la novela griega de amor y aventuras estaba en el candelero en el momento en que Núñez de Reinoso compuso o redactó el Clareo y Florisea. Y ello porque, a partir del descubrimiento, por un soldado alemán, del manuscrito griego, en el saco a la biblioteca del rey Matías Corvino de Hungría, de la Historia etiópica, en 1527, y de su editio princeps en 1534, en Basilea, a cargo del humanista alemán Vincentius Opsopopeus, el texto de Heliodoro, junto con el Leucipa y Clitofonte, de Aquiles Tacio, y, en menor medida, las Pastorales lésbicas, de Longo, no solo había devuelto la primacía al género que floreció entre los siglos I a.C. y IV en la zona de influencia helena de Roma, sino que se había erigido en un modelo literario de referencia en el Renacimiento, gracias a su encumbramiento por los humanistas, principalmente los erasmistas, los preceptistas y el público lector. El humanista toledano Francisco de Vergara, asiduo corresponsal de Erasmo, tradujo las Etiópicas directamente del griego antes de su fallecimiento en 1545; si bien no llegó a publicarse, parece ser que su edición estaba lista para ir al taller en 1548 a cargo de su hermano Juan de Vergara, un año después de la versión francesa de Jacques Amyot (París, 1547), cuatro antes de la latina de Estanislao Warschewiczki (Basilea, 1552) y seis de la castellana de «un amigo de la patria», elaborada sobre la francesa de Amyot, y publicada en la oficina antuerpiense de Martín Nucio en 1554, la cual fue reeditada en Toledo, por Francisco Guzmán, en 1563 y en Salamanca, por Pedro Lasso, en 1581. Como veremos después, el verdadero desarrollo de las derivaciones españolas de la novela de tipo griego no acaeció sino en el siglo XVII, al arrimo de una nueva transliteración de la novela de Heliodoro, la que realizó el médico y humanista Fernando de Mena y que vio la luz en Alcalá de Henares, en la imprenta de Juan Gracián, en 1587, y del éxito que cosechó, pues se volvió a estampar en Barcelona, por Gerónimo Margarit, en 1614, en Madrid, en el taller de Alonso Martín, en 1615, y París, por Pedro Le-Mur, en 1616, el mismo año que Cervantes dejaba terminada, aunque falta de un último pulimiento a causa de su fallecimiento, Los trabajos de Persiles y Sigismunda. Por lo pronto, y como es nítidamente discernible en el Clareo y Florisea, en donde se interpolan en 
calidad de relatos de segundo grado las historias de Narcisiana y Altayes y de Casiano, Falanges y Belisenda, la novela helenística "influyó poderosamente en buena parte de los géneros narrativos hispánicos (novela pastoril, cortesana, de cautivos; incluso en la picaresca), como soporte estructural de numerosas narraciones" (Rey Hazas, 1982: 99).

Los libros de pastores, que se fueron abriendo camino progresivamente en el seno de los libros de caballerías a partir del episodio de Beltenebros en el Amadís de Gaula (Muñoz Sánchez, 2004: 30-34), hasta alcanzar carta de ciudadanía con la publicación de La Diana, del portugués Jorge de Montemayor, en Valencia, en las prensas de Joan Mey, en 1558 o 1559, se caracterizan, en efecto, por estar conformados, desde una perspectiva formal, por dos niveles narrativos distintos, uno primario y otro secundario, a saber: la trama principal y los episodios intercalados. Así, La Diana, de Montemayor, que exhibe además, una estructura itinerante, marcada por el viaje, superpone sobre la narración de base, el triángulo amoroso de Sireno, Silvano y Diana, las historias de Selvagia, Felismena, Belisa y Arsileo, Amarílida y Filemón y Duarda y Danteo; algunas de la cuales, por otro lado, están en deuda directa, como es el caso de la de Felismena, con la recepción de la novella italiana en los reinos peninsulares de la Monarquía Hispánica. Y, por supuesto, entre sus páginas se encuentran rasgos provenientes de la ficción caballeresca como, por ejemplo, el rapto de las ninfas a manos de los salvajes, la aparición de Felismena como una doncella guerrera o una virgo bellatrix, lo concerniente a la sabia Felicia y la utilización del "agua encantada", el agua mágica que sana las heridas de don Felis, etc. En su génesis, naturalmente, desempeñaron un papel trascendental tanto la tradición eclógica antigua y española, con Virgilio y Garcilaso de la Vega a la cabeza, como la Arcadia (Nápoles, 1504), de lacopo Sannazaro, bien en italiano, bien en la traducción castellana de Diego de Salazar para el verso y de Diego López de Ayala para la prosa, que se publicó en Toledo en 1547 y se reeditó en Estella en 1547 y, de nuevo, en Toledo en 1549, antes de la composición de La Diana, y la História de Menina e Moça (Ferrara, 1554), de Bernardim Ribeiro.

La Diana, de Montemayor, es uno de los hitos de la prosa de imaginación de este periodo y uno de los pasos decisivos en el camino que 
conduce a la novela moderna, desde la perspectiva, sobre todo, de la novela psicológica, pese a que la mayor parte de los casos de amor que se desgranan en ella se resuelven aún mediante el expediente de la magia, y pese a su idealismo, su platonismo y su naturaleza quintaesenciada. Tuvo, como es sabido, un éxito editorial extraordinario, pues, solo en la segunda mitad del siglo XVI, cosechó veinticinco reediciones y fue traducida a varios idiomas europeos (Fosalba, 1994); fue de inmediato continuada con Los ocho libros de la segunda parte de La Diana (Valencia, 1563), de Alonso Pérez, y con La Diana enamorada (Valencia, 1564), de Gaspar Gil Polo, y en la lejanía por Jerónimo Tejada, en la Tercera Diana (París, 1627), después de haber sido vuelta a lo divino por fray Bartolomé Ponce, en Primera parte de la Clara Diana a lo divino (Zaragoza, 1599), y se tiene certera noticia de otra continuación más, escrita antes de 1582 por Gabriel Hernández, de la que no ha pervivido ningún ejemplar (Castillo Martínez, 2017); y fue, cierto, el texto fundacional de una serie genérica, la novela pastoril española, que sería la segunda más prolífica de los siglos XVI y XVII, tras los libros de caballerías, con más de veinte representantes, aparte de los mencionados, en poco más de setenta años de historia -de 1558 o 1559 a 1633-, y en la que se vieron envueltos ni más ni menos que Cervantes y Lope de Vega ${ }^{8}$ (Avalle-Arce, 1975; Castillo Martínez, 2005).

Una de las claves del triunfo de la fórmula literaria de La Diana (Montero, 1996: XXXV-LXI) estribó en la agregación de material ajeno, incluido a continuación en versiones sucesivas, como así sucedió en la edición barcelonesa de 1561, impresa en la oficina de Jaime Cortey, que incorporó la Historia de Alcida y Silvano, novela en verso del propio Montemayor, que se repitió en la antuerpiense de Juan Steelsio del mismo año. El hito se produjo

\footnotetext{
${ }^{8}$ Algunos de los títulos más significativos son: Los diez libros de Fortuna de Amor (Barcelona, 1573), de Antonio de Lofrasso; El pastor de Fílida (Madrid, 1582), de Luis Gálvez de Montalvo; La Galatea (Alcalá, 1585), de Miguel de Cervantes; el Desengaño de celos (Madrid, 1586), de Bartolomé López de Enciso; las Ninfas y pastores de Henares (Alcalá, 1587), de Bernardo González de Bobadilla; El pastor de Iberia (Sevilla, 1591), de Bernardo de la Vega; Los cinco libros intitulados de la enamorada Elisea (Valladolid, 1594), de Jerónimo de Covarrubias Herrera; la Arcadia (Madrid, 1598), de Lope de Vega; El prado de Valencia (Valencia, 1600), de Gaspar Mercader; La constante Amarilis (Valencia, 1607), de Cristóbal Suárez de Figueroa; Siglo de Oro en las Selvas de Erífilie (Madrid, 1608), de Bernardo de Balbuena; y Los pastores de Belén (Madrid, 1612), de Lope de Vega; La Cintia de Aranjuez (Madrid, 1629), de Gabriel de Corral; y Los pastores del Betis (Trani, 1633), de Gonzalo de Saavedra.
} 
cuando en la edición de Valladolid de 1561-1562, salida de las prensas de Francisco Fernández de Córdoba, aparte de la Historia de Alcida y Silvano, de la Historia de los muy constantes e infelices amores de Píramo y Tisbe, fábula en verso de Montemayor, de la traducción del Triunfo de amor de Petrarca, llevada a cabo por Álvaro Gómez, y de varios poemas más como material extra, se interpoló en el cuerpo del texto, al final del libro IV, en el corazón de la obra, puesto en boca de Felismena, el Abencerraje y la hermosa Jarifa. Se ignora cuándo pudo haberlo escrito Montemayor y si su interpolación en el centro de su ficción pastoril fue una decisión personal suya u obra de un avispado librero editor que supo calibrar el papel que jugaría en su recepción. Mas lo significativo es consignar que la de La Diana representa una de las tres versiones que han llegado hasta nosotros de la espléndida novela corta. Las otras dos, que preceden y suceden a la de Montemayor, son la denominada versión "crónica", que se publicó en 1561 con el título Parte de la crónica del ínclito Infante don Fernando que ganó Antequera, y la versión que Antonio de Villegas incluyó en su Inventario, que se publicó en 1565, en Medina del Campo. De la primera de ellas, la versión crónica, se han conservado dos ediciones del mismo año, una se imprimió en Cuenca, en la casa de Juan de Cánova, encuadernada junto con La Diana de Montemayor, pero como entidad textual independiente al final. El texto, precedido de una dedicatoria a Jerónimo Jiménez Dembún, está sesgado, carece de la mitad final de los folios. La otra se publicó exenta, en Toledo, en el taller de Miguel Ferrer, el 12 de octubre de 1561, según reza el colofón, y, aunque el texto carece del primer folio del pliego $\mathrm{A}$, en el que rezaría tanto el título, y tendría cabida el comienzo de la dedicatoria al prócer aragonés, como, seguramente, los preliminares legales estipulados por la pragmática libraria de 1558, lo hizo editorialmente disfrazada, a buen seguro como reclamo comercial, cual si fuera un representante de la narración caballeresca breve (Torres Corominas, 2008: 300-303): un pequeño volumen en octavo, con un grabado en la portada que representa un duelo entre dos caballeros, seguido de un extenso título, y con la tipografía gótica. El Abencerraje, que constituye otro de los hitos de la prosa de imaginación del periodo y que es otra obra fundacional, hubo de escribirse a lo largo de la década de los cincuenta al calor de "una coyuntura muy concreta de la historia 
del reino de Aragón, en que los señores de vasallos moriscos, apoyados económicamente por estos últimos, se enfrentaron con el Santo Oficio" (Carrasco Urgoiti, 2001: 60). En él no solo se dan cita las técnicas del relato de la época con las características de la novella italiana, se entremezclan en sutil y ponderado equilibrio el idealismo y el realismo, sino que esconde un precioso mensaje de virtud, tolerancia y bonhomía; en fin, una pequeña obra maestra.

Por su naturaleza conversacional, los coloquios permiten la mescolanza de temas y estilos, de realismo y fantasía, de diálogo y narración; la variedad de géneros, formas y modos; el contenido misceláneo; la sátira y la crítica de las costumbres contemporáneas y la controversia intelectual. En la década de 1550-1560, sobre los rieles de los diálogos clásicos, humanistas y del primer Renacimiento, de la tradición de los Coloquios de Erasmo, los diálogos y relatos de Luciano de Samósata - de quien en 1550, en Estrasburgo, se había publicado una importantísima selección anónima, atribuida a Francisco de Enzinas, de los Diálogos de Luciano, no menos ingeniosos que provechosos, traducidos de griego en lengua castellana ${ }^{9}$, y al año siguiente, en 1551, en el mismo lugar y por el mismo traductor, el primer libro de la Historia verdadera- y aun del Asno de oro, de Apuleyo, se redactó una serie de coloquios de muy variada factura y alcance que, desde diversas perspectivas, "aportó su granito de arena en la aparición de la novela moderna" (Riley, 2001: 239), algunos éditos y otros inéditos, entre los que se cuentan los Coloquios matrimoniales (Sevilla, 1550), de Pedro Luján, los Coloquios satíricos (Mondoñedo, 1553), de Antonio de Torquemada, El Crotalón (h. 1556), atribuido a Cristóbal de Villalón, El viaje de Turquía (h. 1556), los Diálogos de filosofía natural y moral (Granada, 1558), de Pedro de Mercado, y Los coloquios de Palatino y Pinciano (1550-61), de Juan Arce de Otálora ${ }^{10}$.

Con la publicación del Lazarillo de Tormes a comienzos de la década de 1550 no solo nació, en estado de gracia, la novela picaresca española, sino

\footnotetext{
${ }^{9}$ La selección está conformada, sin ilación macrotextual, por el Diálogo de la amistad (o Tóxaris), que ya había sido traducido exento por fray Ángel Cornejo en 1548, el Diálogo de Carón (o Los contempladores), el Diálogo del Gallo o del sueño, Menipo en los abismos (o Diálogo de los muertos) y Menipo sobre las nubes (o lcaromenipo).

${ }^{10}$ Sobre los diálogos, véase Bataillon (1998: 643-692), Gómez (1998 y 2000), Ferreras (2002), Malpartida Tirado (2005) y Vian Herrero y Baranda (2010).
} 
que se sentaron las bases de la novela moderna ${ }^{11}$. La irrupción de la anónima novelita supuso una quiebra, una agitación, una conmoción literaria sin precedentes en la literatura española, si descontamos el caso de La Celestina. Su genial autor daba en confeccionar una ficción rebosante de sabrosa cotidianidad, deliberadamente ambigua desde el párrafo inicial y protagonizada por un miserable de vívida conciencia que, habiendo logrado el oficio real de pregonero y alcanzado la cumbre de toda buena fortuna como marido cartujo, reconstruye, en apologia pro vita sua, su itinerario desde su infausto nacimiento, a petición de un misterioso personaje, "Vuestra Merced", que no cuenta con más presencia diegética que la que él mismo le confiere y con el que mantiene una relación que no se aclara ni se declara textualmente. Nacía, cierto, la autobiografía literaria, admirablemente trabada y organizada desde una perspectiva tan única cuanto unipersonal, en la que el hombre, Lázaro, se explica a sí mismo por medio del roce con el mundo y desde un punto de arribo. Solo que lo hacía enmascarada en forma de epístola, dependiente de los manuales de escribientes de la época y adscrita bien a la retórica del género judicial o bien a la del epidíctico o encomio paradójico, que en todo caso era el tradicional vehículo para contar confidencias, confesiones o el discurso de una vida. Lo más sorprendente es que esta autobiografía armónicamente construida instituía el pluriperspectivismo y la polisemia semántica, la ambigüedad y el relativismo moral, transidos de finísima ironía, burlona parodia y sátira crítica, como clave medular de su ética y de su estética. Normal, pues, que fuera un éxito fulgurante de público y ventas: se conocen con certeza dos ediciones antuerpienses de 1553 y cuatro de 1554, publicadas en Burgos, Medina del Campo, Alcalá de Henares y Amberes (Rodríguez, 2015 y 2016); y ello a pesar de que estamos lejos de conocer con solvencia y rigor su génesis y su difusión, antes de su interdicción, probablemente acaecida en 1554 o 1555, y su inclusión en 1559 en el índice de libros prohibidos de Fernando de Valdés. Normal, pues, que nadie, hasta lectores tan capaces como Mateo Alemán y Cervantes, discerniera todo el potencial que se escondía tras la oblicua

\footnotetext{
${ }^{11}$ Los dos párrafos que siguen remiten, con algunas modificaciones y añadidos, a Muñoz Sánchez (2018: 158-159).
} 
ficcionalidad de la anonimia, el realismo cómico y la autodiégesis contrastada de un humilde mozo de muchos amos.

El iter de la novela picaresca presenta paralelismos y similitudes con las otras series genéricas nacidas en esta década. De hecho, su parábola es harto pareja a la que experimenta la novela española de tipo griego, junto con la que domina el panorama de la prosa de ficción en el siglo XVII, y la novela morisca. Pero, de entrada, es con la novela pastoril con la que se vincula, habida cuenta de que el impacto ocasionado por sus textos inaugurales comportó su inmediato alargamiento en forma de continuaciones, a las que siguieron otras elaboradas mucho tiempo después. El Lazarillo, que en la edición de Alcalá de Henares alberga ya varias interpolaciones, que afectan incluso al final, abriendo un portillo a su continuabilidad: "de lo que aquí adelante me sucediere, avisaré a Vuestra Merced", tuvo, en efecto, una Segunda parte, también anónima, publicada en Amberes en 1555. Lo que separa al continuador de la edición antuerpiense de Alonso Pérez y Gaspar Gil Polo es que él no supo (o no quiso) colegir a cabalidad la obra de su predecesor. De suerte que, entre las varias posibilidades que le brindaba el Lazarillo, optó por la sátira político-social camuflada de una historia de transformaciones al modo de Apuleyo y Luciano, que trata irónicamente el romance, e imprimió un gusto misceláneo al conjunto. Tiempo después, Cervantes, en su estupendo Coloquio de los perros, al establecer metadiscursivamente la historicidad del género picaresco, notará la ilación entre la fábula, la sátira menipea, el sermo milesius, la tradición celestinesca y la novela picaresca. Es así que La Segunda parte del Lazarillo de Tormes no logró conformar, sobre la base del original, el diseño estructural que prescribiera el género picaresco. Sin embargo, y pese a su disparidad, ambas obras, a partir de las dos primeras ediciones de Amberes de 1555, la de Martín Nucio y, en especial, la de Guillermo Simón, no solo se editaron juntas, sino que, probablemente, se leyeron como dos partes de un único, unitario y coherente texto. Por otro lado, así como La Diana, de Montemayor, tuvo setenta años después de su publicación una continuación, la de Jerónimo Tejada, así también le sucederá al Lazarillo con la Segunda parte (París, 1620), de Juan de Luna. 


\section{Tercer periodo (1595-1605)}

El tercer momento crucial de la prosa de imaginación española de los siglos XVI y XVII lo constituye el decenio que transcurre de 1595 a 1605, en el cual se prescribieron e institucionalizaron tres flamantes series genéricas -el romance morisco, el romance de amor y aventuras de tipo griego y la novela picaresca-, cuyos textos fundacionales se habían redactado en la década de 1550-1560, y nació la novela moderna. Fueron años de perturbación política, marcados por el cambio de reinado entre Felipe II y su hijo, Felipe III, que supuso una transformación completa de ambiente y de mentalidad, y por el controvertido traslado de la sede de la Corte de Madrid a Valladolid. E igualmente, de revolución cultural, caracterizados por el predominio del teatro comercial, que se había convertido en la primera industria cultural de la historia de Occidente cuyo volumen de negocio y beneficio era tan productivo y rentable que viabilizaba el nacimiento de la escritura profesional, y el triunfo arrollador de la fórmula dramática de la Comedia nueva pergeñada por Lope de Vega, así como por el significativo progreso de la imprenta y el desarrollo del mercado literario.

En 1595 se publicaba en Zaragoza por Ángel Tabano la Historia de los bandos Zegríes y Abencerrajes o Primera parte de las guerras civiles de Granada, del murciano Ginés Pérez Hita, con la que, en comunión con el Abencerraje, nacía el género de la novela morisca o de frontera, habida cuenta de que las coordenadas espacio-temporales de sus relatos se sitúan en el contexto histórico de la toma de Granada. La novela de Pérez de Hita, que había de conocer, aparte de cierta difusión manuscrita, la friolera de una treintena de reediciones desde su publicación hasta finales del siglo XVII -y había de hacer las delicias del joven Leandro Fernández de Moratín-, desborda en todos los órdenes y sentidos al Abencerraje hasta imprimirle la forma de una narración extensa. Quizá su sello más característico no sea otro que su talante heterogéneo, propiciado por la inserción en el curso de la trama, además de un sinfín de digresiones, episodios y lances que desvían la atención del asunto principal de la aniquilación del linaje de los Abencerrajes, de un elevado número de romances fronterizos, moriscos y de otros temas, que no solo pautan la prosa, sino que mantienen hasta cierto punto una relación orgánica 
con ella. Por otro lado, la Historia de los dos bandos acentúa aún más la relación del género con la ficción caballeresca, siempre dentro de los límites de un idealizado y romantizado trasfondo real e histórico, por cuanto, al despliegue de "temas amorosos, lances caballerescos y grandes cuadros áulicos, como las suntuosas fiestas de toros y cañas", que retratan la "Granada nazarí como una corte de caballeros y damas que hacen del lance, el juego ecuestre y la galanterías su razón de existir" (Carrasco Urgoiti, 2001: 64), se une que se presenta, ya desde la portada, como la traducción al castellano de un libro escrito en árabe por un historiador moro que presenció los hechos que recrea: "Agora nuevamente sacada de un libro arábigo, cuyo autor de vista fue un moro llamado Aben Hamín, natural de Granada, tratando desde su fundación". Pérez de Hita escribió en 1597 la Segunda parte de las guerras civiles de Granada, centrada en la relación, entre histórica y ficcional o fabulosa, de la Rebelión de las Alpujarras, en las que participó a las órdenes del marqués de los Vélez. Aunque se baraja la posibilidad de que el texto pudiera haberse estampado antes, quizá en Alcalá en 1604, lo cierto es que no se conservan ejemplares anteriores a las impresiones de Cuenca y Barcelona de 1617; pese a su maurofilia, se reeditó en cinco ocasiones más a lo largo del siglo. Solo en 1833 se editaron las dos partes -tan distintas entre sí- juntas. La serie genérica de la novela morisca, la más exigua de la época, se completa con la Historia de Ozmín y Daraja, que Mateo Alemán interpoló en la Primera parte de Guzmán de Alfarache (I, 8).

A partir de la edición castigada de López de Velasco de 1573, que se publica junto con la Propadallia de Torres Naharro, el Lazarillo conoce una segunda etapa editorial entre 1573-1595 (Montero, 2007), en la que se reedita ora exento, en 1586, en Tarragona, tal vez en el taller de Juan Felipe Mey, y en 1589, en Valencia, por Miguel Borrás; ora incrementado por el primer tratado de la Segunda parte como si fuera el octavo, en 1595, en Leiden, en la oficina plantiniana, cuyo texto deriva de la edición de Martín Nucio de 1554; ora seguido de la Segunda parte, en 1587, en Milán, por lacobo Maria Meda a instancias de Antonio de Antoni, cuyo texto sigue también el de Martín Nucio ${ }^{12}$.

\footnotetext{
12 Estos párrafos remiten, con sensibles modificaciones, a Muñoz Sánchez (2018: 161-162).
} 
Ello comportó que la picaresca impregnara la atmósfera literaria finisecular ${ }^{13}$, lo que terminaría redundado en la prescripción del género. Con todo, aparte de las referencias explícitas al Lazarillo que manifiesta el Diálogo intitulado el Capón (h. 1597), de Narváez de Velilla, en especial en la autodiégesis apicarada de Velasquillo, nadie se atrevió a emular su ejemplo hasta que Mateo Alemán publicó, en 1599 en Madrid, la Primera parte de Guzmán de Alfarache ocasionando un revuelo sin precedentes en el mercado editorial, pues entre 1599 y 1604 se reeditó hasta en veintidós ocasiones.

La novela de Mateo Alemán, de una admirable perfección morfológica, no se constituía sin más en una servil continuación genética y genérica del Lazarillo, sino que lo readaptaba profundamente conforme a sus intereses creadores e ideológicos. Mantenía la autobiografía como eje del relato, pero eliminando su envoltura epistolar. Reducía, sin eliminar, la ambigüedad, la ironía y la pluralidad de significados en aras de una visión monocorde de la realidad, emanada de la compleja interioridad del pícaro: la postura desde la cual el yo narrador, escarmentado, en búsqueda de la perfección ética y en disconformidad ideológica con su vida pasada, adoctrina al lector sobre la condición humana y la necesidad de una reforma sociomoral del hombre. Mateo Alemán quebrantaba el pacto autobiográfico del anónimo quinientista y de su continuador de Amberes, basado textualmente en la identidad de autor, narrador y personaje, al disociar nítidamente al autor empírico del yo narrador, acentuando el talante marcadamente ficcional de la autobiografía. Asimismo, modificaba notablemente al receptor ficticio de la autobiografía de Lázaro, el Vuestra Merced, para que su pícaro dialogara directamente, más bien monologase en atención a, con un narratario polivalente y plurivocal no identificado y consigo mismo en sostenida reflexión e introspección, desdoblándose en locutor y alocutario. Mateo Alemán, además, convertía al protagonista del anónimo en un pícaro con todas las de la ley, hacía de Guzmán un disidente y un infractor ocasional que bordea la marginalidad en el

\footnotetext{
${ }^{13}$ Conviene no olvidar, de hecho, que Lope de Vega, entre 1593 y 1606, escribió una serie de comedias (El caballero del milagro, El rufián Castrucho, El anzuelo de Fenisa, El caballero de Illescas), ambientadas en Italia, muy libres, transgresoras y satíricas, "de tono realista urbano y truhanesco", que Joan Oleza (1991; y véase Sobejano, 2020: 199-207) no ha dudado en denominar como "comedias de pícaros" o "subgénero picaresco". A lo que conviene sumar el acto I de El rufián dichoso de Cervantes, escrito probablemente hacia 1596, al menos en una versión primigenia de la final.
} 
seno de la sociedad; para, en la segunda parte, forjar un delincuente profesional que trasciende la picardía: fuera del embajador francés y del cómitre de la galera ya no sirve a ningún amo. Al mismo tiempo que le relacionaba con un estrato humano y un cuerpo social más amplio que el de Lázaro, que engloba a todos los estamentos y profesiones, y que está en sintonía con sus mayores aspiraciones. E, igual de importante, extendía y ampliaba el Lazarillo en su aspecto y en su contenido hasta imprimirle la forma de una narración de largo recorrido, tal y como había hecho Ginés Pérez Hita en la Primera parte de las guerras civiles de Granada con el Abencerraje y la hermosa Jarifa. Así, a la narración pura y a las expansiones meditativas se unen todo tipo de digresiones, novelas sueltas y cuentos, anécdotas y chascarrillos, dichos y sentencias... y mil cosas más. Había nacido, pues, la gran novela barroca y, en comunión con el Lazarillo, el género novela picaresca, cuya institucionalización acaeció prácticamente de forma simultánea a su prescripción.

A continuación del Guzmán, y tras su estela, se escribieron en los años siguientes, ya como emulación, ya como respuesta, cuatro novelas picarescas, que constituyen su fase de legitimación: La segunda parte de la vida del pícaro Guzmán de Alfarache (1602), firmada por Mateo Luján de Sayavedra, que entre 1602 y 1604 alcanzó la sensacional cifra de diez impresiones, la Segunda parte de la vida de Guzmán de Alfarache, atalaya de la vida humana (Lisboa, 1604), de Mateo Alemán, que se reeditó cuatro veces en 1605, El guitón Onofre (1604), de Gregorio González, y La pícara Justina (Medina del Campo, 1605), de López de Úbeda, que se reeditó ese mismo año y en 1608. A ello que hay que sumar que, en 1599, el Lazarillo principia una nueva etapa editorial, la tercera, vinculada al éxito de ventas de la Primera parte del Guzmán de Alfarache, en la que fue objeto de un nuevo expurgo, que extiende los pasajes suprimidos en el anterior; salió a luz en la imprenta madrileña de Luis Sánchez, a costa de Juan Berrillo. Existen tres ediciones de ese año, dos de las cuales se publicaron aisladamente, y una con El Galateo español, de Gracián Dantisco, texto con el que sería reeditado en 1605, 1607, 1609, 1612, 1620,1621 y en varias ocasiones a lo largo del siglo XVII. 
Aunque la novela española de amor y aventuras contaba con los antecedentes del Clareo y Florisea, de Núñez de Reinoso, que solo conoció la edición de 1552 de Venecia, y la Selva de aventuras, de Jerónimo de Contreras, que se publicó, primero, en siete libros, en 1565 en Barcelona y, después, ampliada a nueve, en 1582 en Alcalá, así como las dos traducciones de la Historia Etiópica, de Helidoro, la de "un amigo de la patria" de 1554 y la de Fernando de Mena de 1587, la institucionalización del género no se produjo sino con la publicación en 1604 en Sevilla, de El peregrino en su patria. Es harto probable que a Lope de Vega le rondara las mientes redactar una obra a imitación del Teágenes y Cariclea, por cuanto era un texto de actualidad que gozaba de un prestigio literario enorme; tanto, que acababa de ser canonizado como épica amorosa en prosa por Alonso López Pinciano, en su Filosofía antigua poética (Madrid, 1596). Y como tal lo habría de consignar Lope en un famoso paso de La dama boba, en que la culta Nise le enseña a su criada Celia no solo que "también hay poesía en prosa", sino que el "griego poeta divino" supo componer "una historia amorosa, / digna de aplauso y teatro", que, basada en "el artificio griego", es prosa poética, no historial, y, en consecuencia, "es hermosa, / varia, culta, licenciosa, y escura aun a ingenios raros. / Tiene mil exornaciones / y retóricas figuras" (Lope de Vega, 2020: 362). Se trata, además, de un afán y una empresa que Lope estaba poniendo en práctica por esos años, como se echa de ver en la escritura tanto de La hermosura de Angélica (Madrid, 1602), que se funda en el Orlando furioso, de Ariosto, como de la Jerusalén conquistada (Madrid, 1609), que sigue a la Gerusalemme liberata, de Torquato Tasso, con el propósito de adquirir reputación y fama literarias. Hay que tener, igualmente, en consideración que la versión ampliada de la Selva de aventuras, que era un éxito de ventas y público, se acababa de reeditar en 1600 , en 1602 y en 1603. Y no se puede descartar que El peregrino no sea una suerte de confrontación y contestación literaria al apabullante éxito obtenido por Mateo Alemán con la Primera parte de Guzmán de Alfarache.

A rebufo de El peregrino, que se reeditó en 1604 en Sevilla y en Barcelona, en 1605 en Barcelona, en 1608 en Bruselas y en 1618 en Madrid, y en competición con él, Cervantes compuso Los trabajos de Persiles y Sigismunda, que se publicó, póstumamente, en Madrid en 1617, haciendo las 
delicias del público lector, ya que se reeditó en cinco ocasiones más ese mismo año y se tradujo dos veces al francés en 1618 y una al inglés en 1619. El mismo año del Persiles, vio la luz la traducción de Diego Ágreda y Vargas de Los más fieles amantes Leucipe y Clitofonte, historia griega, de Aquiles Tacio. Tras las rectificaciones llevadas a cabo por Lope de Vega, que había nacionalizado el género, rebajado sus figuras a personajes propios de la comedia de capa y espada, estructurado la trama en torno a una doble historia amorosa, la de Pánfilo y Nise, que hace las veces de principal, y la de Celio y Finea, que le sirve de contrapunto y de complemento, y potenciado el mensaje religioso de índole contrarreformista con la inserción, al final de los cuatro primeros libros, de los cinco de que se compone la obra, de sendos autos sacramentales -El viaje del alma, Las bodas del alma y el amor divino, La Maya y El hijo pródigo-, la novela de Cervantes y la traducción de Ágreda devolvían el aura clásica y la dimensión internacional al género. Un género que alcanzaría su esplendor en la década de 1620-1630, con la anónima Los amantes peregrinos Angelia y Lucenrique (h. 1623-1625), la Historia de Hipólito y Aminta (Madrid, 1627), de Francisco de Quintana, la Historia de las fortunas de Semprilis y Genorodano (Madrid, 1629), de Juan Enríquez de Zúñiga, Eustorgio y Clorilene. Historia moscovita (Madrid, 1629), de Enrique Suárez de Mendoza, antes de difuminarse, como le sucedía a la serie picaresca, "hacia otros géneros como el cortesano y el alegórico" (González Rovira, 1996: 203) con El león prodigioso (Madrid, 1636) y Entendimiento y verdad, amantes filosóficos (Alcalá, 1673), de Gómez de Tejada, y con El Criticón (1651, 1653 y 1657), de Baltasar Gracián, que es un auténtico crisol.

Tal vez, como la máscara autorial de Miguel de Cervantes dice en el prólogo de El ingenioso hidalgo don Quijote de la Mancha, engendró, en la cárcel Real de Sevilla, en la que fue preso por orden del juez Vallejo a finales de septiembre de 1597, hasta mediados de abril de 1598, la idea de un texto protagonizado por un viejo hidalgo de aldea ocioso que pierde el juicio por la lectura tan intensa como masiva de libros de caballerías; la cual le servía para novelizar (y desarticular) el debate de la preceptiva neoaristotélica a propósito de la dialéctica entre historia y poesía, en tanto en cuanto la mente desquiciada de su protagonista consideraba verdadero -histórico- lo que no era sino 
verosímil -poético-: la ficción de los libros de caballerías, al mismo tiempo que le permitía reflexionar a propósito del impacto que produce el consumo de los libros de entretenimiento en los receptores de la primera etapa del mercado editorial. El proyecto hubo de ir madurando desde el comienzo en la mente de Cervantes como un libro largo, en virtud de la extensión habitual de los imponentes infolios caballerescos que ridiculizaba a la par que homenajeaba, que rondaban entre doscientos y trescientos folios de media, y de los modelos con los que factiblemente operaba, sobre todo el Orlando furioso, de Ariosto. Desde el punto de vista estructural, la trama medular del Ingenioso hidalgo se cimenta, en efecto, sobre el principio vertebrador del viaje, el constante deambular errante del caballero en el perseguimiento de honra y prez, que posibilita, conforme a las contingencias del azar y a los incidentes propios del camino, el surgimiento de la peripecia y el encuentro con personajes de todo tipo y condición, y que es lo que le imprime esa índole episódica a la narración; si bien, la trabazón de las distintas aventuras es bastante sólida por cuanto hay una evolución en su tratamiento, en el comportamiento de la realidad y las diferentes perspectivas narrativas de presentarla y en la conducta y modo de afrontarla de un héroe que actúa o hace lo mismo que reflexiona, piensa y habla. E igualmente, sobre el lugar del reposo y descanso del caballero andante: el espacio social de la corte y el castillo, en donde practica la cortezia, el fino amor y el juego del torneo, subrogado transparentemente a la baja por las ventas del ventero socarrón (II-III) y de Juan Palomeque el Zurdo (XVI-XVII, XXVI-XXVII y XXXII-XLVII), y el espacio solitario del bosque o la floresta, representado por Sierra Morena (XXIII-XXX). Pero el estímulo, el espaldarazo final lo constituyó el clamoroso éxito de la Primera parte de Guzmán de Alfarache, un volumen en cuarto de 256 folios, impreso en Madrid, en casa del licenciado Várez de Castro, en 1599, que le daba la pauta de una ficción cómica en prosa de aire realista, multiforme, pluritemática y de variedad tan enciclopédica como heterogénea. A su arrimo, traza Cervantes los dos magistrales pasos del Ingenioso hidalgo en que lo caballeresco se confronta irónicamente con lo picaresco, a saber: la conversación que mantiene el ventero que arma caballero a don Quijote con su ahijado en la primera salida (III) y el célebre encuentro con la cadena de galeotes en que va preso Ginés de 
Pasamonte (XXII), y redacta la versión más antigua de Rinconete y Cortadillo, que se menciona en el capítulo XLVII y que probablemente coindice con la del códice de Porras de la Cámara. Con todo, a Cervantes no hubo de entusiasmarle un ápice la alternancia de consejas y consejos, de narración y admonición, de relato y discurso, que informa la narración primopersonal del pícaro, pese a su sutil imbricación, puesto que a la ficción no le corresponde instruir ni dar lecciones para la vida, y menos aún la mala baba misantrópica y cínica que rezuma contra esa "república de hombres encantados" que es el inmundo mundo. Sucede que el Ingenioso hidalgo no es un libro de caballerías, y no lo es por los temas vertebrales de la trama, que son de orden metaliterario, ni por los personajes, ni por la ambientación espacio-temporal, ni por no anular ni suspender la experiencia de lo real del lector, y además es ambigua, irónica, perspectivista, metanarrativa, polisémica, dialógica, pluriestilística, polifónica y de carácter híbrido o sintético; como tampoco es una novela picaresca, por cuanto Cervantes se aparta tan radical y decididamente de la poética común del género que no constituye en ningún aspecto o sentido una variante de ella (Muñoz Sánchez, 2018: 87-111, y en prensa). Antes bien, constituye la superación consciente de ambos géneros en una realidad literaria flamante que, andando el tiempo, se denominará 'novela moderna'. El ingenioso hidalgo don Quijote de la Mancha, sin alcanzar el apabullante éxito editorial del Guzmán de Alfarache, que no obstante no se volvería a publicar hasta 1615 ya reunidas las dos partes a causa del impacto del texto cervantino, tuvo una segunda edición en el mismo 1605, año en que se imprimió dos veces tanto en Lisboa como en Valencia, en 1607 se estampó en Bruselas, en 1608 en Madrid, en 1610, en Milán y en 1611 en Bruselas; se tradujo al inglés en 1612 y al francés en 1614 . Como es bien sabido, en ese mismo año vio la luz, en Tarragona, el espurio y desabrido Segundo tomo del ingenioso hidalgo don Quijote de la Mancha, de "Alonso Fernández de Avellaneda", y, al año siguiente, en 1615 en Madrid, la Segunda parte del ingenioso caballero don Quijote de la Mancha, que, siendo una continuación cabal, es casi un texto nuevo, probablemente el mejor que escribió su autor.

\section{Cuarto periodo (1618-1630)}


El cuarto y último punto culminante en el desarrollo de la prosa de imaginación española de los siglos XVI y XVII lo constituye el entorno de 1620. Se singulariza por la evolución y disolución de la serie genérica de la novela picaresca, por la ductilidad y difuminación de las formas y la hibridación genérica, en la que descuella la labor de dos novelistas semi profesionales, y por la prescripción e institucionalización de los libros de novelas (cortas).

En el gran arco que cubre la novela picaresca, los años que van de 1618 a 1626, concurrentes con el turbulento cambio de reinado de Felipe III a Felipe IV, constituyen su momento de mayor profusión ${ }^{14}$. Pues, efectivamente, se publican un total de seis textos, que asumen la poética común del género; despliegan y profundizan algunos de los rasgos que habían quedado insinuados, sugeridos o propuestos -discurso autodiegético anecdótico y homogéneo o enciclopédico y heterogéneo, cautiverio, latrocinio, relato carcelario, sátira mordaz, parodia deconstruccionista, usurpación social, impostura, proceso de degradación, discurso aberrante, etc.-. Al tiempo que lo renuevan, en coalescencia con su contexto inmediato y según el genio de cada autor, tanto en la forma como en el fondo -es decir: en la autobiografía, que se sitúa a veces en el seno de un marco dialogístico o de una situación de interlocución, y en la trayectoria del pícaro, que puede ser igualmente la de un hidalgo pobre, un ladrón presidario, un bonachón sin apenas mácula 0 un infame buscavidas extramoral, pero todos viatores, arribando aun a las Indias como jornada o fin del itinerario, todos solitarios, todos seres semi marginales, todos críticos de una sociedad fraudulenta y engañosa y todos, sobre actores y espectadores, incansables narradores-. A saber: La vida del escudero Marcos de Obregón (Madrid, 1618) de Vicente Espinel, La desordenada codicia de los bienes ajenos (París, 1619) de Carlos García, La segunda parte del Lazarillo (París, 1620) de Juan de Luna, el Lazarillo de Manzanares (Madrid, 1620) de Juan Cortés de Tolosa, Alonso, mozo de muchos amos (Madrid, 1624, y Valladolid, 1626) de Jerónimo Alcalá Yáñez, y la Historia de la vida del Buscón (Zaragoza, 1626) de Francisco de Quevedo. Después del texto de Quevedo, cuya circulación manuscrita parece ser que fue ligeramente anterior a la edición

${ }^{14}$ Los dos párrafos que siguen remiten, con sensibles modificaciones, a Muñoz Sánchez (2018: 166-169). 
príncipe (Alonso Veloso, 2020), solo dos obras merecen ser incluidas por derecho propio en la nómina del género: La niña de los embustes, Teresa de Manzanares, de Alonso de Castillo Solórzano, publicada en Barcelona en 1632, y la anónima Vida y hechos de Estebanillo González, hombre de buen humor, impresa por vez primera en Amberes en 1646.

La disolución o, mejor, readaptación de la novela picaresca está íntimamente relacionada con el experimento de nuevas fórmulas narrativas de índole mixta o híbrida, de materia singularmente notoria en la obra de creación de nuevos autores, Caso paradigmático es el del prolífico escritor madrileño Alonso Jerónimo de Salas Barbadillo (Piqueras Flores, 2018), que imbrica la picaresca con la novela cortesana, pero sustituyendo el registro paródico bufonesco de La pícara Justina por una modalidad cómica correctora de costumbres viciadas, en La hija de Celestina (1612) y su alargamiento, La ingeniosa Elena (1614), cuyo feliz maridaje estaba destinado a obtener una amplísima notoriedad a lo largo del siglo XVII: solo hace falta repasar la producción de otro profesional de las letras, Alonso de Castillo Solórzano -como vemos más abajo-, para percatarse de ello. Se sirve del patrón celestinesco en, por ejemplo, las comedias en prosa El sagaz Estacio (1620) y La sabia Flora malsabidilla (1621). Y utiliza marcas de la serie o rasgos característicos de la configuración del pícaro en obras tales como El caballero puntual (1614), donde narra la carrera arribista de superchería de don Juan de Toledo, un "hijo de la piedra", y su desenmascaramiento; en El sutil cordobés Pedro de Urdemalas (1620), repleta de discretas travesuras picarescas, o en El necio bien afortunado (1621), en la que don Félix Ceñudo, su protagonista, cuenta, en extensa relación primopersonal, su vida pseudopicaresca a Dorotea, con el propósito, tras haberla raptado, de desposarla. Por otro lado, la novela picaresca se aproxima, hasta confundirse, a las biografías, más o menos ciertas, de soldados, como el Discurso de mi vida (ms. 1630), de Alonso de Contreras, o los Comentarios del desengaño de sí mismo (ms. 1680), del Duque de Estrada, y la Varia fortuna del soldado Píndaro (Lisboa, 1626), de Céspedes y Meneses. A la sátira lucianesca, impulsada, tras la divulgación erasmiana de Luciano, por la publicación del Somnium (1581), de Justo Lipsio y, sobre todo, por la circulación manuscrita e impresa -Sueños y discursos 
(1627), Desvelos soñolientos (1627) y Juguetes de la niñez (1631)- de los Sueños, de Quevedo, así como de su Discurso de todos los diablos (1628), cuyos máximos representantes son El diablo Cojuelo (1641), de Luis Vélez de Guevara, y El siglo pitagórico y Vida de don Gregorio Guadaña (1644) y La torre de Babilonia (1649), que incluye la novelita de aire picaresco El marqués de la Redoma, ambos de Antonio Enríquez; al costumbrismo, como Periquillo de las gallineras (1668) y otras obras del fecundo Francisco Santos. A los libros de viajes semiturísticos atestados de digresiones, como La tercera parte de Guzmán de Alfarache (c. 1650), de Machado da Silva. A la novela cortesana apicarada, truhanesca o bufonesca, como los textos de Castillo Solórzano, Las harpías de Madrid (1631), las Aventuras del bachiller Trapaza (1637) y La garduña de Sevilla (1642). E, incluso, en ponderada síntesis con otros géneros literarios -curiosamente la novela helenística- y didáctico-morales, a la gran epopeya educativa de Baltasar Gracián, El Criticón (1651, 1653, 1657).

A esta reformulación de la novela picaresca ayudó sobremanera la propuesta de la Junta de Reformación al Consejo de Castilla de que suspendiera la concesión de licencias para imprimir "libros de comedias, novelas ni otros deste género"; licitación aceptada que duró desde el 6 de marzo de 1625 hasta finales de 1634. Ello comportó, ni que decir tiene, la interrupción editorial y comercial de los géneros señalados; también su desarrollo natural, más en el caso de las novelas, en tanto las comedias se siguieron representando. Pero a la postre propició que autores, impresores, editores y libreros buscaran formas de burlar la denegación de licencias: ora con ediciones contrahechas, ora aprovechando la diversidad de legislación y jurisdicciones referidas al libro de los distintos reinos peninsulares, ora con agudeza e ingenio poniendo títulos que subrayen su Deleitar aprovechando o su hibridez genérica cual La Dorotea, acción en prosa, a la par que destierren el término novela.

El libro de novelas, que había hecho tímidamente su aparición en la segunda mitad del siglo XVI a raíz de la redacción de las inéditas Novelas (1563-1566), del cronista e historiador Pedro de Salazar, de El Patrañuelo (Valencia, 1567), del librero valenciano Joan de Timoneda, de las inéditas Novelas en verso (1570-1580), de Cristóbal de Tamariz, cobró carta de 
ciudadanía a comienzos del siglo XVII con la publicación en 1609 en Pamplona, de las Noches de invierno, de Juan Eslava, en 1613 en Madrid, de las Novelas ejemplares, de Cervantes, y en 1615 en Madrid, de Corrección de vicios, de Salas Barbadillo. Pero no fue sino en 1620 cuando el género se consolidó definitivamente con la publicación de cuatro obras distintas entre sí que se erigirán en modelos discursivos: el ya citado Lazarillo de Manzanares con otras cinco novelas (Madrid, 1620), de Cortés de Tolosa, las Novelas morales útiles por sus documentos (Madrid, 1620), de Diego de Ágreda y Vargas, los Guía y avisos de forasteros (Madrid, 1620), de Antonio Liñán y Verdugo, y Casa del placer honesto (Madrid, 1620), de Salas Barbadillo (González Ramírez, 2019).

Aunque las novelas cortas seguirían encontrando acomodo en el seno de libros misceláneos, como las Novelas a Marcia Leonarda, de Lope de Vega, repartidas entre La Filomena (1621) y La Circe (1624), o, en general, de cuerpos mayores, como la novela de Los tres maridos burlados, de Tirso de Molina, insertada en Los cigarrales de Toledo (1624), el hecho es que el asentamiento como fórmula genérica de los libros de novelas comportaría, con el paso del tiempo, la delimitación de la prosa de imaginación extensa de la prosa de imaginación breve, en tanto en cuanto cada una había encontrado su propio cauce de expresión y difusión.

\section{Recapitulación}

Pío Baroja, en el "Prólogo casi doctrinal sobre la novela" que antecede a $\mathrm{La}$ nave de los locos (1925), escribía lo siguiente: "¿Hay un tipo de novela? Yo creo que no. La novela, hoy por hoy, es un género multiforme, proteico, en formación, en fermentación; lo abarca todo: el libro filosófico, el libro psicológico, la aventura, la utopía, lo épico; todo absolutamente" (Baroja, 1980: 18). En efecto, la novela moderna, como fruto tardío de las letras, es el género literario que goza de mayor libertad formal, dada la variedad de enfoques y temas que presenta y representa. Esto se debe posiblemente a que, como afirmaba Mijail Bajtín (1989: 449-450), "la novela es el único género en proceso de formación, todavía no cristalizado", por lo que "su estructura dista mucho de estar consolidada, y aún no podemos prever todas sus posibilidades". Máxime 
cuando tiende a situarse en el presente desde el que se escribe y trata como materia de la realidad inmediata, lo que le otorga ese dinamismo, ese progreso vital o estar en mutación constante, pues evoluciona al mismo tiempo en que lo hace la sociedad, y responde y se adapta a la situación cultural en que se produce y, de acuerdo con ella, reinterpreta y readapta las formulaciones preexistentes. Es decir, en tanto en cuanto es un género aún en desarrollo, no hay un modelo canónico o paradigmático de novela moderna, aunque la novela realista-naturalista del siglo XIX haya sido tomada o considerada como tal en repetidas ocasiones. Lo que sí se puede tener por cierto y seguro es que su génesis o su invención se produjo en la prosa de imaginación española de los siglos XVI y XVII, en especial, aunque no solo, en la línea que une La Celestina, el Lazarillo y el Guzmán de Alfarache con el Quijote y las Novelas ejemplares.

Una prosa de imaginación que, entre 1489 y 1664, año en que se reúnen en un volumen las tres partes de El Criticón, y que puede ser considerado como su simbólico final, conoció, como hemos podido ver, un desarrollo espectacular, en torno a cuatro peiriodos o momentos culminantes, situados en sendos periodos críticos: la consolidación, frente a los señores feudales, de la monarquía autoritaria de los Reyes Católicos y la transformación de la nobleza guerrera en cortesana por el auge de los ejércitos profesionales, el primero, y los cambios de reinado de Carlos V a Felipe II, de Felipe II a Felipe III, y de Felipe III a Felipe IV, los otros tres. Y que se articuló por medio de una sorprendente batería de géneros, modos y formas: los libros de caballerías, que dominaron ampliamente todo el siglo XVI; la ficción sentimental, que tuvo vigencia hasta 1548; La Celestina y su progenie, que logró su acmé entre 1534 y 1554; la novela pastoril, que alcanzaría su máximo apogeo durante la segunda mitad del siglo XVI; la novela morisca, la novela de amor y aventuras y la novela picaresca, que describen un itinerario evolutivo harto similar, en concreto las dos últimas, que fueron las predominantes en el siglo XVII, hasta la disgregación de la novela con la obra maestra de Gracián. Los representantes más conspicuos de las diferentes series genéricas son, al mismo tiempo, los grandes éxitos de ventas del periodo (Whinnom, 1980): La Celestina, del "antiguo autor" y Fernando de Rojas, de largo la primera; la 
Primera parte de Guzmán de Alfarache, de Mateo Alemán; la Historia de los bandos Zegríes y Abencerrajes o Primera parte de las guerras civiles de Granada, de Ginés Pérez de Hita; La Diana, de Jorge de Montemayor; Don Quijote, de Miguel de Cervantes; el Amadís de Gaula, de Garci Rodríguez de Montalvo; la Cárcel de amor, de Diego de San Pedro; y el Lazarillo de Tormes. Conviene destacar, por último, que, del significativo elenco de escritores, en su mayoría autores de una única obra de ficción en prosa, descuellan cinco novelistas: Feliciano de Silva, en la primera mitad del siglo XVI, Miguel de Cervantes y Lope de Vega, a caballo entre los siglos XVI y XVII, y Alonso Jerónimo de Salas Barbadillo y Alonso de Castillo Solórzano, en el siglo XVII, flanqueados por tres espléndidos prosistas: fray Antonio de Guevara, Francisco de Quevedo y Baltasar Gracián.

\section{El cambio de paradigma (1550-1560): hacia la novela moderna}

El monográfico que aquí se presenta se centra en el segundo de los cuatro momentos estelares que hemos subrayado. Su propósito no es otro que ofrecer, a través de sus once apartados, un análisis lo más abarcador posible del periodo, tanto de cuestiones generales como particulares, con especial atención a los géneros y los textos más representativos.

La contribución de Eduardo Torres Corominas ofrece un exhaustivo panorama de carácter histórico a propósito del cambio de reinado entre Carlos V y Felipe II y las consecuencias que tuvo en todos los órdenes de la vida española, sobre todo en la espiritual, cultural y literaria. La de Mercedes Blanco discurre, de manera general, sobre las traducciones al castellano que se llevaron a cabo de obras de la antigüedad clásica y de la modernidad en el trentenio 1540-1570 y el papel que desempeñaron en el desarrollo de la literatura española; proporciona, al final, un completo y utilísimo listado de traducciones. La de Aude Plagnard se centra, al socaire de la dicotomía cervantina de épica histórica y épica literaria, en las transliteraciones que se realizaron de poemas épicos en el decenio 1550-1560 y el impacto que tuvieron en la génesis de la épica española. La de Francisco Javier Escobar Borrego rastrea la influencia de Apuleyo y Luciano en la literatura del periodo, con calas en la obra de Cervantes y de Quevedo. 
Aurelio Vargas Díaz-Toledo se centra en los libros de caballerías de la década de 1550-1560, concretamente en el Espejo de príncipes y caballeros, de Diego Ortúñez de Calahorra, texto fundacional no solo de un ciclo caballeresco, que se prolongaría hasta bien entrado el siglo XVII, sino de un cambio de paradigma en la serie genérica con el nacimiento de los libros de caballerías de entretenimiento. Miguel Ángel Teijeiro examina las relaciones literarias de Alonso Núñez de Reinoso, el contexto literario en que se compuso el Clareo y Florisea y la obra en cuestión. Cristina Castillo Martínez analiza las claves literarias de Los siete libros de la Diana, de Jorge de Montemayor, texto fundacional de la novela pastoril española, y el papel que ocupa en el camino hacia la novela moderna. Ilaria Resta aborda la influencia de la novella italiana en la construcción del Abencerraje y la hermosa Jarifa, así como de la funcionalidad que adquieren sus características compositivas en las tres versiones de la novelita que han llegado hasta nosotros.

Rafael Malpartida Tirado estudia tres de los diálogos más distintivos de la década, los Coloquios satíricos, de Antonio de Torquemada, El Crotalón, atribuido a Cristóbal de Villalón, y El viaje de Turquía, y su contribución a la invención de la novela moderna. Valentín Núñez Rivera indaga en el peculiar itinerario vital de Lázaro en la Segunda parte, a fin de determinar la relación de la anónima novela con la literatura sapiencial, sobre la que puede que descanse su sentido último. Aldo Ruffinatto, por fin, desbroza el Lazarillo de Tormes con el objetivo de desentrañar las características que lo convierten en un eximio precursor de la novela moderna.

No quisiera cerrar estas páginas sin dar mi más sincero agradecimiento a Josefa Badía y, en su nombre, al equipo humano de Diablotexto, por haberme brindado la posibilidad de coordinar un monográfico para la revista. Igualmente, a todos los colaboradores del monográfico, por su generosidad, su gentileza, su disposición y su dedicación y porque sin su participación y su compromiso no podría haber salido adelante. Y, por último, a todas las personas que me han ayudado a que esta aventura acabe felizmente. 


\section{Bibliografía:}

AlONSO Veloso, María José (2020). "La difusión manuscrita temprana del Buscón de Quevedo, a la luz de una noticia de época desatendida". Revista de Literatura, LXXXII.1, pp. 59-93.

Avalle-ARCE, Juan Bautista (1975). La novela pastoril española. Madrid: Istmo. BARANDA, Consolación (1992). "De Celestinas: problemas metodológicos". Celestinesca, 16.2, pp. 3-32.

Baranda, Nieves (1995). Historias caballerescas del siglo XVI. Ed. N. Baranda, Madrid: Turner-Castro, 2 vols.

BAROJA, Pío (1980). La nave de los locos. Madrid: Caro Reggio.

BATAILlon, Marcel (1998). Erasmo y España. Trad. de Antonio Alatorre, México DF: Fondo de Cultura Económica.

BAJTín, Mijail (1995). Teoría y estética de la novela. Trad. de Helena S. Kriúkova y Vicente Cazcarra, Madrid: Taurus.

Bognolo, Anna (1997). La finzione rinnovata. Meraviglioso, corte e avventura nel romanzo cavalleresco del primo Cinquecento spagnolo. Pisa: Edizione ETS.

CarRasco Urgoiti, María Soledad (2001). "La novela morisca". En María Soledad Carrasco Urgoiti, Francisco López Estrada y Félix Carrasco, La novela del siglo XVI. Madrid/Frankfurt: Iberoamericana/Vervuert, pp. 51-87. Castillo Martínez, Cristina (2017). "Tras los pasos de la Diana de Jorge de Montemayor: continuaciones, imitaciones, plagio". En David Álvarez Roblin y Olivier Biaggini (eds.), La escritura inacabada. Continuaciones literarias y creación en España. Siglos XIII a XVII. Madrid: Casa de Velázquez, pp. 163-185.

Castillo Martínez, Cristina (ed.) (2005). Antología de los libros de pastores. Alcalá de Henares: Centro de Estudios Cervantinos.

CÁtedra, Pedro M. (2007). El sueño caballeresco. De la caballería de papel al sueño real de don Quijote. Madrid: Abada.

CORTIJO OCAÑA, Antonio (2001). La evolución genérica de la ficción sentimental de los siglos XV y XVI. Género literario y contexto social. Londres: Tamesis. 
DEYERMOND, Alan D. (1995). "La ficción sentimental: origen, desarrollo y pervivencia». Estudio preliminar a Diego de San Pedro, Cárcel de amor. Ed. Carmen Parrilla, Barcelona: Crítica, pp. vii-xxxiii.

DeYermond, Alan D. (1993). Tradiciones y puntos de vista en la ficción sentimental. México: UNAM.

EISENBERG, Daniel (1982). Romances of Chivalry in the Spanish Golden Age. Newark: Delaware, Juan de la Cuesta.

EISENBERG, Daniel y María del Carmen MARín PINA (eds.) (2000). Bibliografía de los libros de caballerías castellanos. Zaragoza: Prensas Universitarias de Zaragoza.

FERRERAS, Jacqueline (2002). Los diálogos humanísticos del siglo XVI en lengua castellana. Murcia: Universidad de Murcia.

FosalBA, Eugenia. (1994). "La Diana" en Europa. Ediciones, traducciones e influencias. Barcelona: Universitat Autònoma de Barcelona.

GómEZ, Jesús (2000). El diálogo renacentista. Madrid: Laberinto.

GómEZ, Jesús (1998). El diálogo en el Renacimiento español. Madrid: Cátedra.

GonZÁlez RAmíreZ, David (2021). "El incunable del Decamerón en castellano (Sevilla, 1496): todo problemas". Revista de Filología Española, Cl.1, pp. 169-198.

GonzÁlez RamíreZ, David (2019). Madrid, 1620. De la carrera editorial al nacimiento de un nuevo escritor: Alonso Castillo Solórzano y la narrativa de su tiempo". Criticón, 135, pp. 29-48.

GonZÁlez RoviRA, Javier (1996). La novela bizantina de la Edad de Oro. Madrid: Gredos.

GuiJarro Ceballos, Javier (2007a). El Quijote cervantino y los libros de caballerías: calas en la poética caballeresca. Alcalá de Henares: Centro de Estudios Cervantinos.

GuiJarro Ceballos, Javier (2007b). "Los libros de caballerías, género en prosa, de tradiciones medievales e innovaciones renacentistas". En M. Á Teijeiro Fuentes y J. Guijarro Ceballos, De los caballeros andantes a los peregrinos enamorados. La novela española del Siglo de Oro. Madrid: Eneida/UNEX, pp. 27-71. 
GwARA, Joseph J., y E Michael GeRLI (eds) (1997), Studies on the Spanish Sentimental Romance (1440-1550). Redefining a Genre. Londres: Tamesis.

Haro Cortés, Marta, y José Manuel Lucía Megías (eds.) (2020). Libros de caballerías castellanos. 3. Poética, historia y ficciones. Valencia: Universitat de València.

Haro Cortés, Marta, y José Manuel Lucía Megías (eds.) (2019). Libros de caballerías castellanos. 2. Géneros literarios, corpus y difusión. Valencia: Universitat de València.

INFANTES, Víctor (1996). "El género editorial de la narrativa caballeresca breve". Voz y Letra, 7, pp. 127-132.

INFANTES, Víctor (1991). "La narrativa caballeresca breve". En Ma E. Lacarra (ed.), Evolución narrativa e ideología de la literatura caballeresca. Bilbao: Universidad del País Vasco, pp. 165-182.

Lucía Megías, José Manuel, y Emilio José Sales Dasí (2008). Libros de caballerías castellanos (siglos XVI y XVII). Madrid: Laberinto.

LuCíA MegíAs, José Manuel (2000). Imprenta y libros de caballerías. Madrid: Ollero y Ramos.

MALPARTIDA TIRADO, Rafael (2005). Varia Lección de plática áurea. Un estudio sobre el diálogo renacentista español. Málaga: Universidad de Málaga.

MARín PINA, Ma Carmen (1999). "Ideología del poder y espíritu de cruzada en los libros de caballerías del periodo reinado fernandino". En Esteban Sarasa Sánchez (ed.), Fernando II de Aragón, el Rey Católico. Zaragoza: Institución Fernando el Católico, pp. 87-108.

MARGUET, Christine (1999). "De Leucipa y Clitofonte de Aquiles Tacio a la Historia de los amores de Clareo y Florisea de Alonso Núñez de Reinoso: un caso de reescritura novelesca entre traducción y creación". Criticón, 76, pp. 9-22.

MONTERO, Juan (2007). "Tras las huellas de un Lazarillo perdido (Valencia, Miguel Borrás, 1589)". Studia Aurea, IV. Consultado el 24-06-2021: http://www.studiaaurea.com/articulo.php?id=44. 
Montero, Juan (1996). Prólogo a Jorge de Montemayor, La Diana. Estudio Preliminar de J. B. Avalle-Arce, ed. J. Montero. Barcelona: Crítica, pp. XXVII-XCIII.

MUÑOZ SÁNCHEZ, Juan Ramón (en prensa). "«Ha de ser una y varia»: Los modelos compositivos de El ingenioso hidalgo don Quijote de la Mancha". En S. Pérez Abadín, R. Marnoto y D. González Ramírez (eds.), Entre Italia, Portugal y España. Ensayos de recepción literaria. Santiago de Compostela: Universidade de Santiago de Compostela,

MuÑoz SÁNCHEZ, Juan Ramón (2018). Estudios de literatura del Siglo de Oro. Turín: Università degli Studi di Torino (Anejos de Artifara, 2).

MUÑOZ SÁNCHEZ, Juan Ramón (2004). "El Amadís de Gaula como posible fuente de La Galatea". Nueva Revista de Filología Hispánica, LII.1º, pp. 29-44.

NúÑEZ RIVERA, Valentín (2015). Cervantes y los géneros de la ficción. Madrid: SIAL/Prosa Barroca.

OlEZA, Joan (1991). "Las comedias de pícaro de Lope de Vega: una propuesta de subgénero". En M. Diago y T. Ferrer (eds.), Comedias y comediantes. Valencia: Universitat de València, pp. 165-188.

PIQUeRAS FloRES, Manuel (2018). La literatura en el abismo. Salas Barbadillo y las colecciones de metaficciones. Vigo: Academia del Hispanismo.

RAMOS NoGALES, Rafael (2016). "Dos nuevas continuaciones para el Espejo de príncipes y caballeros", Historias fingidas, 4, pp. 41-95.

REY HAZAS, Antonio (1982). "Introducción a la novela del Siglo de Oro (Formas de narrativa idealista)". Edad de Oro, I, pp. 65-105.

Rıco, Francisco (2011). Estudios y anexos a "Lázaro de Tormes", Lazarillos de Tormes. Ed. F. Rico, Madrid: RAE, pp. 91-205.

RILEY, Edward C. (2001). La rara invención. Estudios sobre Cervantes y su posteridad literaria. Trad. de Mari Carmen Llerena, Barcelona: Crítica.

RodríGueZ, Arturo (2016). "Las dos ediciones del Lazarillo de Amberes de 1553: en 8avo y en 16avo". Etiópicas (2016), XII, pp. 91-103.

RodríGuez, Arturo (2015). "La edición del Lazarillo de Amberes de 1553: fuentes documentales". Artifara, 15, pp. 11-22. 
ROHLAND DE LANGBEHN, Regula (1999). La unidad genérica de la novela sentimental española de los siglos XV y XVI, Londres: Queen Mary and Westfield College.

SobeJANO, Gonzalo (2020). "El pícaro hablador" y otros estudios sobre prosa narrativa deI XVII. Ed. J. M. Martínez Torrejón, Madrid: Cátedra.

TEIJEIRO FUENTES, Miguel Ángel (2007). "La novela bizantina: De la Antigüedad pagana al contrarreformismo cristiano". En M. Á Teijeiro Fuentes y J. Guijarro Ceballos, De los caballeros andantes a los peregrinos enamorados. La novela española del Siglo de Oro. Madrid: Eneida/UNEX, pp. 111-175.

TEIJEIRO FUENTES, Miguel Ángel (1988). La novela bizantina. Apuntes para una revisión del género. Cáceres: Universidad de Extremadura.

TORRES COROMINAS, Eduardo (2008). Literatura y facciones cortesanas en la España del siglo XVI. Estudio y edición del "Inventario" de Antonio de Villegas. Madrid: Polifemo.

VEGA, Lope de (2020). La dama boba. Ed. Marco Presotto. En Ocho comedias magistrales. Ed. del grupo PROLOPE al cuidado de Agustín Sánchez Aguilar. Madrid: Castro, pp. 351-453.

Vian Herrero, Ana, y Consolación Baranda (2010). Diálogos españoles del Renacimiento. Córdoba: Almuzara.

WHINNOM, Keith (1983). The Spanish sentimental romance 1440-1550 (A critical bibliography). Londres: Grant and Cutler.

WHINNOM, Keith (1980). "The Problem of the 'Best-Seller' in Spanish GoldenAge Literature". Bulletin os Spanish Studies, 57, pp. 189-198. 